ВЕСТНИК ПНИПУ. ГЕОЛОГИЯ. НЕФТЕГАЗОВОЕ И ГОРНОЕ ДЕЛО

BULLETIN OF PNRPU. GEOLOGY. OIL \& GAS ENGINEERING \& MINING

ISSN 2224-9923

Tom/Volume 15 №21 2016

http://vestnik.pstu.ru/geo/

УДК 553.982.2

Article / Статья

(C) PNRPU / ПНИПУ, 2016

\title{
DETERMINATION OF BOTTOMHOLE PRESSURE BY USING MULTIVARIATE STATISTICAL MODELS (ON EXAMPLE OF FORMATION TL-BB YURCHUKSKOIE FIELD)
}

\section{I.A. Chernykh}

LLC LUKOIL-PERM (62 Lenina st., Perm, 614990, Russian Federation)

\section{ОПРЕДЕЛЕНИЕ ЗАБОЙНОГО ДАВЛЕНИЯ С ПОМОЩЬЮ МНОГОМЕРНЫХ СТАТИСТИЧЕСКИХ МОДЕЛЕЙ (НА ПРИМЕРЕ ПЛАСТА ТЛ-ББ ЮРЧУКСКОГО МЕСТОРОЖДЕНИЯ)}

\author{
И.А. Черных \\ ООО «ЛУКОЙЛ-ПЕРМЬ» (614990, Россия, г. Пермь, ул. Ленина, 62)
}

Received / Получена: 06.10.2016. Accepted / Принята: 15.10.2016. Published / Опубликована: 02.12.2016

\section{Ключевые слова:}

показатели эксплуатации скважин, забойное давление, механизированные скважины, необорудованные глубинными измерительными системами, методика определения забойного давления, статистический анализ, факторы, влияющие на величину забойного давления, корреляция, пошаговый линейный дискриминантный анализ, линейная дискриминантная функция, многомерная математическая модель, разнонаправленность влияния факторов, регрессионный анализ, множественная регрессия, работоспособность модели.

\section{Key words:}

well operation indicators, bottomhole pressure, mechanized wells, unequipped depth measuring systems, method of determining bottomhole pressure, statistical analysis, factors affecting the value of bottomhole pressure; correlation, stepwise linear discriminant analysis, linear discriminant function, multidimensional mathematical model, different directions of influence factors, regression analysis, multiple regression, models functionality.

\begin{abstract}
Проблема определения забойных давлений в механизированных добывающих скважинах, не оборудованных глубинными измерительными системами, является актуальной для многих нефтяных месторождений Пермского края. На практике, при отсутствии специальных приборов под скважинным насосом, забойное давление определяют путем пересчета динамического уровня. При таком подходе основную сложность представляет расчет плотности газожидкостной смеси, достоверность которого бывает низкой из-за влияния многочисленных осложняющих факторов. В настоящей работе предложен принципиально другой подход к определению забойного давления, рассмотренный на примере одной из добывающих скважин, оснащенных высокоточной глубинной измерительной системой, эксплуатирующей тульско-бобриковскую залежь Юрчукского месторождения. В качестве исходных данных приняты результаты непосредственного измерения забойного давления, а также ряд других показателей ее эксплуатации (дебиты нефти и жидкости, обводненность, динамический уровень, глубина спуска насоса под динамический уровень, давление на устье в затрубном пространстве). Выполненный на первом этапе анализ данных позволил сделать вывод, что забойное давление в период наблюдения изменялось, причем разнонаправленно: сначала постепенно снижалось, затем - увеличивалось. В этой связи исследование влияния показателей эксплуатации на величину забойного давления проведено для трех случаев: для всего периода наблюдений, а также отдельно для периодов его снижения и увеличения. Статистический анализ средних значений и плотностей распределений позволил выделить параметры, оказывающее влияние на величину забойного давления, и установить, что влияние это разнонаправленно. На заключительном этапе построены многомерные статистические модели, учитывающие разнонаправленное влияние показателей эксплуатации на забойное давление. Проверка «работоспособности» разработанных моделей выполнена на примере трех других скважин этого же объекта разработки. Она подтвердила целесообразность использования разработанных моделей для определения величин забойного давления по известным значениям показателей эксплуатации скважин и всего предложенного подхода в целом.
\end{abstract}

The problem of determining BHP in production wells not equipped with depth measuring systems, it is relevant for many of the oil fields of Perm Krai. In practice, the absence of special devices for downhole pump bottomhole pressure is determined by converting the dynamic level. With this approach, the main difficulty is the calculation of the density of the gas-liquid mixture, the accuracy of which is low due to the influence of numerous complicating factors. In this paper the fundamentally different approach to the definition of bottomhole pressure, considered on one of the well equipped with high-precision depth measurement system, of Tl-Bb layer of Yurchukskoe field. The initial data are direct measurements of downhole pressure, as well as a number of other indicators of its operation (flow rates of oil and liquid, water content, dynamic level, the pump depth below the dynamic level, the pressure of the annulus). The first stage analysis of the data led to the conclusion that the bottomhole pressure during the observation period varied, with different directions: the first is gradually reduced, then - increased. In this regard, the study of influence of operating parameters on the value of BHP held for three cases: for the entire period of observation, as well as separately for the period of its decline and the increase. Statistical analysis of the averages and distribution densities possible to identify the parameters that influence the bottomhole pressure, and found that the effect is mixed. At the final stage the multidimensional statistical models that take into account the effect of multidirectional operating indicators BHP have been built. "Functionality" verification of developed models was made on the example of three other wells of the same development object. This verification confirmed the feasibility of using developed models for determining the values of bottomhole pressure from known values of indicators for well operation and all the proposed approach in general.

Irina A. Chernykh - Head of the Department of Geophysical and Hydrodynamic Studies (mob. tel.: +007 919483 84 30, e-mail: irina.chernykh@lp.lukoil.com).

Черных Ирина Александровна - начальник отдела геофизических и гидродинамических исследований (моб. тел.: +007 9194838430 , е-таil: irina.chernykh@1p.lukoil.com). 


\section{Introduction}

Bottomhole pressure (BHP) is an important parameter characterizing the operation process of each particular well. In this connection, the control over the value of BHP is the basis of the monitoring wells operation [1-4].

With the aim of quality control for the well operation producing oil fields of Fund LLC "LUKOIL-PERM" are equipped with various types of depth measurement systems. Thus, on considered in this paper TulaBobrikovsky deposits of Yurchukskogo field about $30 \%$ of the wells production fund are equipped with such systems. In other wells the value of BHP is determined by converting the measured values directly to a dynamic level [5-12]. Matching of the selected conversion method with real geological and physical conditions is the most important aspect. Today LLC "LUKOIL-PERM" is used a number of techniques that can determine the bottomhole pressure. They use the model of fluid flow in a well, not considering all of the processes occurring in the borehole while moving there multiphase fluid thereon. Similar findings were obtained by the authors in [13].

In this regard, the development of fundamentally different technique based on mathematical processing accumulated for each data object and creating multidimensional statistical models are relevant aims [14-16].

In order to develop such a methodology in this study production data of wells equipped with depth measuring systems were used, where direct pressure measurements at the pump intake were repeatedly made. These measurements much more accurately recalculated into bottomhole given to the oil-water contact surface than the dynamic level [17]. Parameters, which are likely to have an impact on BHP are selected of the total list of field data:

- the depth of the dynamic level $H_{d}$;

- watering B;

- liquid rate $Q_{l}$

- oil rate $Q_{o}$;

-depth of downhole pump submersion lowers the dynamic level $H_{\text {subm }}$;

- temperature $T$;

- well-head pressure $P_{\mathrm{WHP}}(\mathrm{WHP})$.

\section{Research of wells operating parameters influence on the value of BHP}

Research of operation parameters influence on the BHP is made on the example of the well 882 , that is characterized by the maximum number of measurements $(\mathrm{n}=98)$ for the period from 16 December 2011 to 17 July 2015. BHP changing $P_{B H P}$ in time $t$ is depicted in Fig. 1.

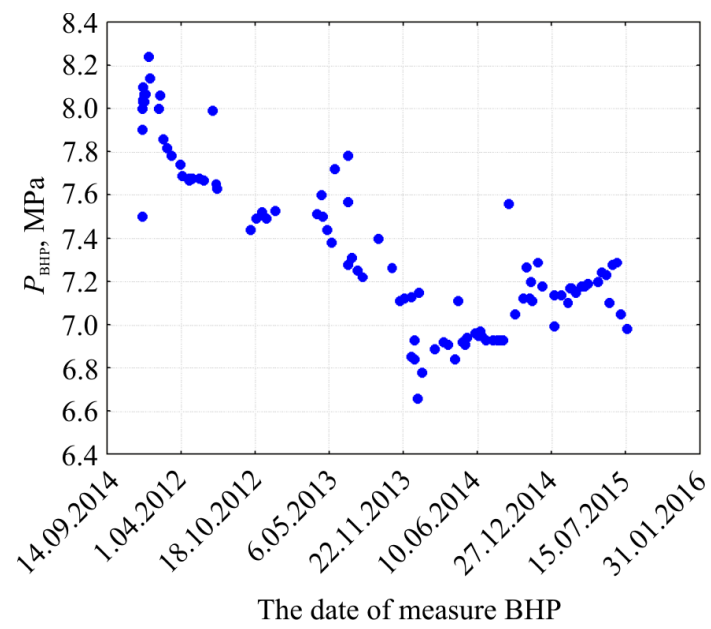

Fig. 1. BHP changing $P_{B H P}$ in time

It can be seen that in the period since 16 December 2011 to 30 November 2013 there is quite natural decrease $P_{B H P}$ values, then its regular increase, but with less intensity. The $P_{B H P}$ changing and other indicators was investigated for the whole period of analysis - the sample 1; during the time when the pressure decreased - sample 2; in a time when the pressure rose - sample 3. Average values of the above parameters for samples 2 and 3 are shown in Table 1.

Table 1

Comparing the statistical characteristics of parameters

\begin{tabular}{|c|c|c|c|c|}
\hline \multirow[b]{2}{*}{ Parameter } & \multicolumn{2}{|c|}{ Average values } & \multicolumn{2}{|c|}{ Statistical estimation* } \\
\hline & simple 2 & simple 3 & $\begin{array}{c}\text { Student } \\
\text { criterion } \\
t_{p}\end{array}$ & $\begin{array}{c}\text { Pearson } \\
\text { criterion } \\
\chi^{2} \\
\end{array}$ \\
\hline$P_{B H P}, \mathrm{MPa}$ & $7.6 \pm 0.3$ & $7.1 \pm 0.1$ & $\frac{10.64453}{0.000000}$ & $\frac{74.88653}{0.000000}$ \\
\hline$H_{d}, \mathrm{~m}$ & $827.3 \pm 146.1$ & $835.8=$ & $\frac{-0.26233}{0.793631}$ & $\frac{1.179766}{0.554392}$ \\
\hline$B, \%$ & $6.3 \pm 5.2$ & $3.2 \pm 1.5$ & & $\begin{array}{l}14.59630 \\
0.000679 \\
\end{array}$ \\
\hline$Q_{l}$, & $23.5 \pm 2.5$ & 26 & $\frac{-6.91203}{0.000000}$ & $\frac{42.73306}{0.000000}$ \\
\hline$Q_{o}, \mathrm{t}$ & $18.3 \pm 2.3$ & $20.8 \pm 0.4$ & $\frac{-7.51304}{0.000000}$ & $\underline{48.06495}$ \\
\hline$H_{\text {subm }}, \mathrm{m}$ & $727.7 \pm 146.1$ & $719.2 \pm 175.1$ & $\frac{-0.26233}{0.793631}$ & $\begin{array}{l}1.179766 \\
0.554392 \\
\end{array}$ \\
\hline$T,{ }^{\circ} \mathrm{K}$ & $293.8 \pm 0.5$ & $294.1 \pm 0.1$ & $\frac{-4.2005}{0.000038}$ & $\frac{17.00090}{0.000203}$ \\
\hline$P_{W H P}, \mathrm{MPa}$ & $2.3 \pm 1.4$ & $1.7 \pm 0 . .8$ & $\begin{array}{r}2.38870 \\
0.018864\end{array}$ & $\begin{array}{l}6.731925 \\
0.034529 \\
\end{array}$ \\
\hline \begin{tabular}{|l|}
$P(Z)$, \\
relative value
\end{tabular} & $0.672 \pm 0.328$ & $0.182 \pm 0.088$ & $\frac{9.992116}{0.000000}$ & $\underline{58.21086}$ \\
\hline
\end{tabular}

Remarks: * numerator - the criterion value; the denominator - the level of significance $\alpha$. 
The value $t$ is calculated to evaluate the differences in the average values of indicators as follows:

$$
t_{p}=\frac{\left|X_{1}-X_{2}\right|}{\sqrt{\frac{1}{n_{1}}+\frac{1}{n_{2}}\left(\frac{\left(n_{1}-1\right) S_{1}^{2}+\left(n_{2}-1\right) S_{2}^{2}}{n_{1}+n_{2}-2}\right)}},
$$

where $X_{1}, X_{2}$ - respectively average values of the samples 2 and $3 ; S_{1}^{2}, S_{2}{ }^{2}$ - dispersion parameters in these samples. The difference in the average values is considered statistically significant if $t_{p}>t_{t}$. The value of $t_{t}$ is determined depending on the amount of compared data and the significance level $(\alpha=0.05)$. Table. 1 shows that average values are statistically different by $P_{B H P}, B, Q_{l}, Q_{o}, T, P_{W H P}$.

For a deeper statistical analysis of the study parameters their distribution was investigated. Optimal intervals of indicators values are calculated according to the formula Sturgess:

$$
\Delta X=\frac{X_{\max }-X_{\min }}{1+3,32 \cdot \lg N}
$$

where $X_{\max }, X_{\min }$ - the maximum and minimum values of the index; $N$ - data quantity.

Relative frequency are defined in each interval

$$
P(X)=\frac{N_{k}}{N_{q}},
$$

where $P(X) \quad$ - relative frequency in the k interval for the group ( $q=2$, corresponds to the second sample); $N_{k}$ - number of index $P(X)$ content in the $\mathrm{k}$ interval; $N_{q}$ - sample volume for samples 2 and 3. Pearson statistic $\left(\chi^{2}\right)$ was used for comparing the distributions density of the indicators in the study sample, formula

$$
\chi^{2}=N_{1} N_{2} \sum_{i=1}^{e} \frac{1}{M_{1}+M_{2}}\left(\frac{M_{1}}{N_{1}}-\frac{M_{2}}{N_{2}}\right)^{2},
$$

where $N_{1}, N_{2}$ - respectively, the number of the indicators in these samples 2 and $3 ; M_{1}, M_{2}$ - the number of values that belongs to a predetermined range, respectively, for the two studied samples; $e$ - number of intervals. Values of $\chi^{2}$ criteria are shown in Table. 1. According to this criterion the following indicators are statistically different: $P_{B H P}, B, Q_{l}, Q_{o}, T, P_{W H P}$.

\section{Research of well operation parameters influence on the BHP in view of its changes over time}

$\mathrm{P}_{\mathrm{BHP}}$ change quantification over time for the three previously described samples is maden by

\begin{tabular}{|c|c|c|c|c|c|c|c|c|c|}
\hline & $P_{B H P}$ & $t$ & $H_{d}$ & $\mathrm{~B}$ & $Q_{l}$ & $Q_{o}$ & $H_{\text {subm }}$ & $T$ & $P_{W H P}$ \\
\hline & 1.00 & $-0.76^{*}$ & 0.01 & $0.37^{*}$ & $-0.69^{*}$ & $-0.69^{*}$ & -0.00 & $-0.47^{*}$ & $-0.29^{*}$ \\
\hline$P_{B H P}$ & $\frac{1.00}{100}$ & $\frac{-0.87^{*}}{0.65^{*}}$ & $\overline{\underline{0.20}}$ & $\overline{\underline{0.10}}$ & $\frac{-0.62^{*}}{051^{*}}$ & $\frac{-0.53^{*}}{0.22 *}$ & -0.20 & $\frac{-0.33}{0.12}$ & $\frac{0.27}{0.10}$ \\
\hline & & $\frac{0.05}{1.00}$ & $\begin{array}{l}-0.01 \\
-0.10\end{array}$ & $\frac{0.40}{-0.31^{*}}$ & $0.77^{*}$ & $0.74^{*}$ & $\begin{array}{l}0.01 \\
0.10\end{array}$ & 0.13 & $-0.36^{*}$ \\
\hline$t$ & & $\frac{1.00}{1.00}$ & $\frac{\overline{-0.40}}{-0.20}$ & $\frac{-0.17}{0.83^{*}}$ & $\frac{\overline{0.76^{*}}}{0.80^{*}}$ & $\frac{0.68^{*}}{0.39^{*}}$ & $\frac{\overline{0.40}}{0.20}$ & $\frac{0.05}{0.20}$ & $\frac{-0.27}{0.44}$ \\
\hline & & & 1.00 & $\underline{0.05}$ & $=0.24^{*}$ & $\begin{array}{l}0.07 \\
-0.22^{*}\end{array}$ & $\begin{array}{l}0.20 \\
-0.99^{*} \\
\end{array}$ & $\underline{0.15}$ & $0.33^{*}$ \\
\hline$H_{d}$ & & & $\frac{\overline{1.00}}{100}$ & $\frac{\overline{0.15}}{0.14}$ & $=0.39$ & $\frac{-0.38}{-0.39}$ & $\frac{-0.99^{*}}{-0.99^{*}}$ & $\frac{0.18}{0.22}$ & $\frac{0.28}{0.49}$ \\
\hline B & & & & $\frac{1.00}{1.00}$ & $\frac{-0.31^{*}}{-0.17}$ & $\frac{-0.64^{*}}{-0.60}$ & $\frac{-0.01}{-0.11}$ & $\frac{-0.26}{-0.15}$ & $\frac{-0.02}{-0.08}$ \\
\hline & & & & & & & 0.10 & 0.19 & $-0.41^{*}$ \\
\hline$Q_{l}$ & & & & & $\frac{\frac{1.00}{1.00}}{\frac{1.00}{.00}}$ & $\begin{array}{l}\frac{0.92^{*}}{0.89^{*}} \\
0.81^{*}\end{array}$ & 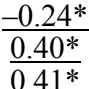 & $\frac{0.30^{*}}{\frac{0.10}{-0.10}}$ & $\frac{\frac{-0.21^{*}}{-0.09}}{-0.52^{*}}$ \\
\hline$Q_{o}$ & & & & & & $\frac{\frac{1.00}{1.00}}{\frac{1.00}{1.00}}$ & $\frac{0.24^{*}}{\underline{0.41^{*}}}$ & $\frac{\frac{0.34 *}{0.15}}{\frac{0.15}{0.27}}$ & $\frac{-0.19}{\frac{-0.03}{-0.36^{*}}}$ \\
\hline$H_{\text {subm }}$ & & & & & & & $\begin{array}{l}\frac{1.00}{1.00} \\
\frac{1.00}{1.00}\end{array}$ & $\frac{-0.15}{\frac{-0.18}{-0.16}}$ & $\frac{-0.33^{*}}{\frac{-0.28^{*}}{-0.49}}$ \\
\hline$T$ & & & & & & & & $\frac{\frac{1.00}{1.00}}{\frac{1.00}{4}}$ & $\frac{0.01}{0.12}$ \\
\hline$P_{W H P}$ & & & & & & & & & $\frac{\frac{1.00}{1.00}}{1.00}$ \\
\hline
\end{tabular}
calculating the correlation coefficient $r$ (Table 2).

Table 2

The correlation matrix

R e m a rks : numerator the sample 1 ; middle row - sample 2 ; bottom line - sample 3 ; $^{*}$ - significant correlations. 
It is evident that for the entire $t$ analysis period (sample 1), there is a statistically significant inverse correlation with $P_{B H P}(r=-0.76)$, for sample 2 , this correlation is more enhanced $(r=-0.87)$, for the third correlation is still statistically significant, but direct $(r=0.65)$. Assuming that the other studied parameters may change over time, for these samples $r$ values were calculated. Analysis showed that $B$ and $P_{W H P}$ have the similar correlations direction. For $\mathrm{B}$ all data correlation is the reverse $(r=-0.31)$, samples 2 and 3 correlation are -0.17 and 0.83 respectively. For $P_{W H P}$ general correlation is also reverse if $r=-0.36$; correlation samples 2 and 3 is equal to -0.27 and 0.44 respectively. The above data show a significant reorganization of the well operation in the studied time period. In order to ensure that the restructuring is not a random process, the hypothesis is put forward: the separate time periods of well operation are different by a range of indicators.

For this, stepwise linear discriminant analysis is applied. The possibility of using it to solve similar problems is given in [18-20]. The entire studied sample was used to develop models of separation options 2, 3. $P_{B H P}$ criterion is not used in separating data on options 2 and 3 . The possibility of constructing a linear discriminant function (LDF) is following. If indicators with the number $i$ denote as $X_{i j}$ the at the observation point and the number $j$ for the second sample, as the result it can be obtained matrix $W_{1}$ order $m$ and $n_{1}$ of the this sample observation results:

$$
W_{1}=\left[\begin{array}{cccc}
X_{11} & X^{12} & \cdot & X_{1 n_{1}} \\
X_{21} & X_{22} & \cdot & X_{2 n_{1}} \\
\cdot & \cdot & \cdot & \cdot \\
X_{m_{1}} & X_{m_{2}} & \cdot & X_{m n_{1}}
\end{array}\right] .
$$

Denote values of the coefficients of the variables with the number $i$ at the point with the number $j$ of the third sample as $X_{i j}^{1}$, a $W_{2}$ matrix order $m \times n_{2}$ am obtained:

$$
W_{2}=\left[\begin{array}{cccc}
X_{11}^{1} & X_{12}^{1} & \cdot & X_{1 n_{2}} \\
X_{21}^{1} & X_{22}^{1} & \cdot & X_{2 n_{1}}^{1} \\
\cdot & \cdot & \cdot & \cdot \\
X_{m_{1}}^{1} & X_{m_{2}}^{1} & \cdot & X_{m n_{2}}^{1}
\end{array}\right],
$$

where $m$ - number of indicators; $n_{1}, n_{2},-$ sample volume.

The centered sums of squares matrix and cross products are compiled, to construct the LDF selective matrix is calculated by them. Then the inverse of sample covariance matrices (the matrix $S$ ) is determined for the coefficients of the linear discriminant function. Then boundary value of the discriminant functions is calculated $\left(R_{o}\right)$, which divides the sample into two subsets. The reliability of classification is calculated using the Pearson criterion $\chi^{2}$. The following linear discriminant function is obtained as a result of this method:

$$
\begin{gathered}
Z=0.525 Q_{o}+0.933 T-0.327 P_{\mathrm{WHP}}- \\
-0.002 H_{\text {subm }}-282.200,
\end{gathered}
$$

if $R=0.679, \chi^{2}=58.21, p=0.000$.

Average $\mathrm{Z}$ value for option 2 is -0.898 , for option 3 is 0.935 . In this function $P(Z)$, the probability values of belonging to this embodiment 2 were calculated. The relation between $Z$ and $P$ $(Z)$ is shown in Fig. 2.

It can be seen that $P(Z)$ value naturally decreases by increasing the quantity $Z$. The average value of $P(Z)$ to sample $2(0.672 \pm 0.328)$; for sample 3 is equal $(-0.182 \pm 0.088)$. Note that the correct recognition by this function was $80 \%$, all the data of embodiment 3 are recognized correctly. Estimates of the average value comparison $P(Z)$ and the density distribution of samples 2 and 3 are made by criterion $t$ and $\chi^{2}$ (see Table 1).

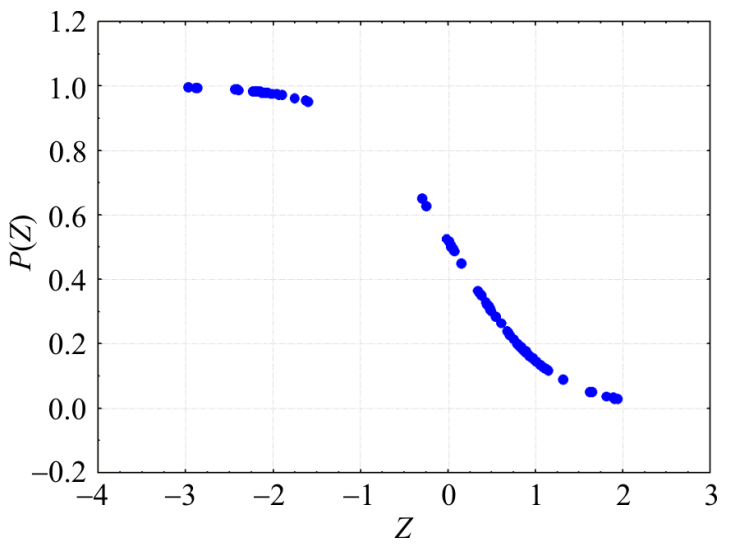

Fig. 2. Function $P(Z)$ on $Z$

The performed statistical analysis of the average values and density distributions showed that $P(Z)$ calculated according to the values $Q_{o}, T, P_{W H P}, N_{\text {subm }}$ is statistically different. It should be noted that the study parameters effect is even in different directions in some cases (see Table 2). This fact confirms the complexity of the proceeding in the well processes in multiphase flow and necessitates the development of a special approach to the determination of BHP, that takes into account the different directions of the many factors influence. 


\section{The multidimensional models development to determine the BHP}

To take into account a variety of different, in some cases multidirectional, the studied parameters effects on $P_{B H P}$ several multidimensional models options are construct using regression analysis. The regression coefficients calculation in the model developed is performed by using the least squares method. The statistical method for studying relationships between the dependent variable $Y$ and one or more independent variables $X_{1}, X_{2}, X_{p}$ is refers as regression analysis. Dependent feature in regression analysis the resultant, independent is called factorial. Usually, several factors effect on the dependent variable. The cumulative effect of all independent factors on the dependent variable is taken into account due to the multiple regression.

In general, multiple regression is estimated by the parameters of a linear equation:

$$
Y=a+b_{1} X_{1}+b_{2} X_{2}+\ldots+b_{p} X_{p} .
$$

In this equation, the regression coefficients (b-coefficients) represent the independent contributions of each independent variable in the prediction of the dependent variable. The regression line expresses the best prediction of the dependent variable $Y$ by the independent variables $X$. In this case, $P_{B H P}$ is dependent characteristic and $N_{d}, B, Q_{l}$, $Q_{o}, N_{\text {subm }}, T, P_{W H P}$ is independent factors.

The concept of residual function is introduced to solve the problem of regression analysis by least squares method:

$$
\sigma(\bar{b})=\frac{1}{2} \sum_{k=1}^{M}\left(Y_{k}-\hat{Y}_{k}\right)^{2} .
$$

Condition of residual function minimum:

$$
\left\{\begin{array} { l } 
{ d \sigma ( b ) - 0 } \\
{ i = 0 \ldots N }
\end{array} \Leftrightarrow \left\{\begin{array}{l}
\sum_{i=1}^{M} y_{i}=\sum_{i=1}^{M} \sum_{j=1}^{N} b_{j} x_{i, j}+b_{0} M, \\
\sum_{i=1}^{M} y_{i} x_{i, k}=\sum_{i=1}^{M} \sum_{j=1}^{N} b_{j} x_{i, j} x_{i, k}+M b_{0} \sum_{i=1}^{M} x_{i, k}, \\
k=1 \ldots N .
\end{array}\right.\right.
$$

Obtained system is a $(N+1)$ linear equations with $(N+1)$ unknowns $b_{0} \ldots b_{N}$.

If left side free member of the matrix

$$
B=\left\{\begin{array}{c}
\sum_{i=1}^{M} y_{i} \\
\sum_{i=1}^{M} y_{i} x_{i, 1} \\
\cdots \\
\sum_{i=1}^{M} y_{i} x_{i, N}
\end{array}\right\},
$$

and the coefficients of the unknowns in the right side equation is submitted as matrix

$$
A=\left\{\begin{array}{ccccc}
M & \sum_{i=1}^{M} x_{i, 1} & \sum_{i=1}^{M} x_{i, 2} & \ldots & \sum_{i=1}^{M} x_{i, N} \\
\sum_{i=1}^{M} x_{i, 1} & \sum_{i=1}^{M} x_{i, 1} x_{i, 1} & \sum_{i=1}^{M} x_{i, 2} x_{i, 1} & \ldots & \sum_{i=1}^{M} x_{i, N} x_{i, 1} \\
\sum_{i=1}^{M} x_{i, 2} & \sum_{i=1}^{M} x_{i, 1} x_{i, 2} & \sum_{i=1}^{M} x_{i, 2} x_{i, 2} & \ldots & \sum_{i=1}^{M} x_{i, N} x_{i, 2} \\
\ldots & \ldots & \ldots & \ldots & \ldots \\
\sum_{i=1}^{M} x_{i, N} & \sum_{i=1}^{M} x_{i, 1} x_{i, N} & \sum_{i=1}^{M} x_{i, 2} x_{i, N} & \ldots & \sum_{i=1}^{M} x_{i, N} x_{i, N}
\end{array}\right\},
$$

matrix equation easily solved by Gauss is obtained. Obtained matrix contains the coefficients of the regression line equation:

$$
X=\left\{\begin{array}{c}
b_{0} \\
b_{1} \\
\cdots \\
b_{N}
\end{array}\right\} .
$$

Constructing multi-dimensional model is made by three samples. Multi-dimensional model is originally constructed by the well 882 with $50 \%$ of the data (option 1). The data are generated in the training set as follows: the data of 16.12.2011values are used first $(n=1)$; data of 17.12.2011 $(n=2)$, is not applyed in the multi-dimensional model construction. They are used at the definition of constructed model "functionality". Thus, the models will be constructed by data having an odd number, and by data having even number will be determined. As a result, the first multivariate model is received and its "functionality" will be estimated. When comparing the $P_{B H P}$ values and values obtained from the $P_{\mathrm{BHPm}}^{1}$ model constructed, options 1 and 2 are finded. The model constructed with the implementation of this condition is as follows:

$$
\begin{gathered}
P_{B H P m}^{1}=71.594-1.67465 Q_{l}- \\
-0.22745 T+0.04276 P_{W H P}+0.44088 B+ \\
+2.13748 Q_{o}+0.00016 H_{\text {subm }},
\end{gathered}
$$

if $R=0.862, p<0.0000$.

The values of $P_{B H P m}^{1}$ were calculated according to this model, which were used for comparison with values $P_{B H P}$ options 1,2 (Fig. 3 ).

Then the constructed model was based on class extracted using LDF method (excluding wells dividing into two even and odd samples). 
According to the data the following model was constructed:

$$
\begin{gathered}
P_{B H P m}^{2}=66.186-0.07541 Q_{l}- \\
-0.19377 T+0.06005 P_{W H P}
\end{gathered}
$$

if $R=0.722, p<0.0000$.

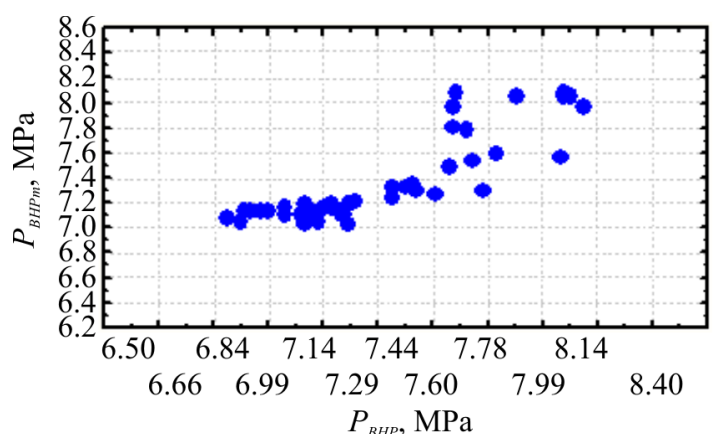

The $1^{\text {st }}$ variant

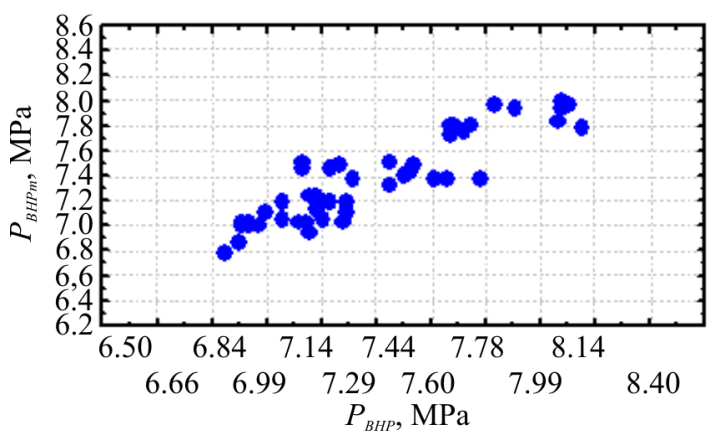

The $3^{\text {rd }}$ variant

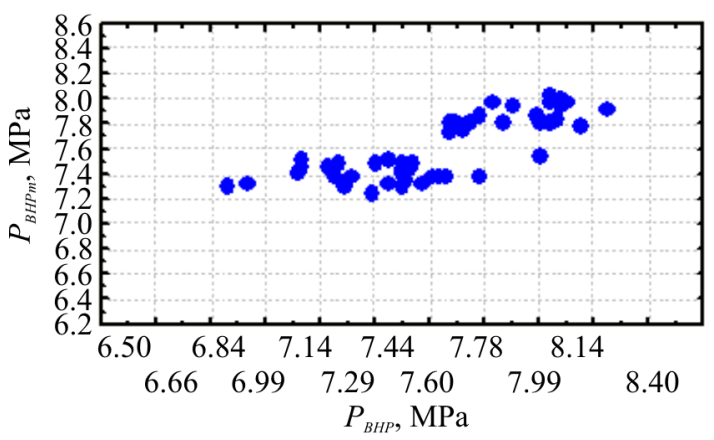

The $5^{\text {th }}$ variant

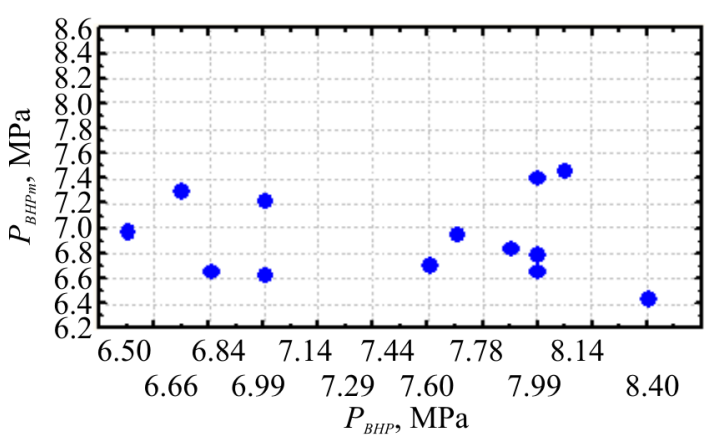

The $7^{\text {th }}$ variant
According to this formula, values were calculated according to embodiment 3 (see Fig. 3). Then according to this model the values of $P_{B H P m}^{2}$ examination sample were calculated. $P_{B H P}$ comparison with $P_{B H P m}^{2}$ for the examination sample is shown in Fig. 3 (option 4).

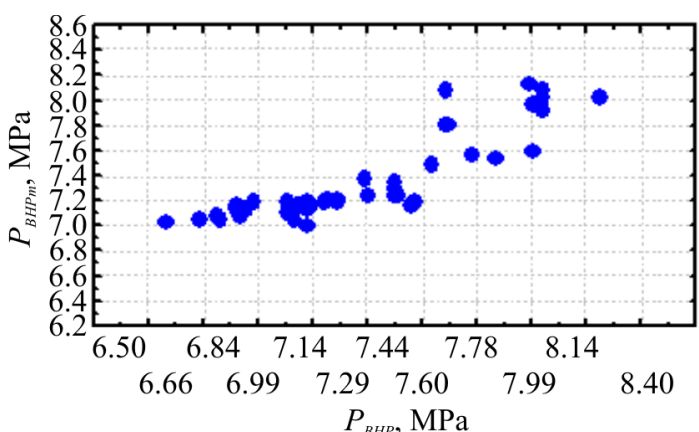

The $2^{\text {nd }}$ variant

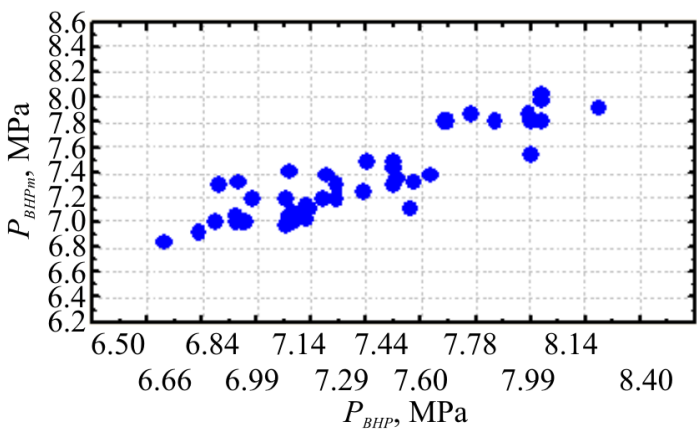

The $4^{\text {th }}$ variant

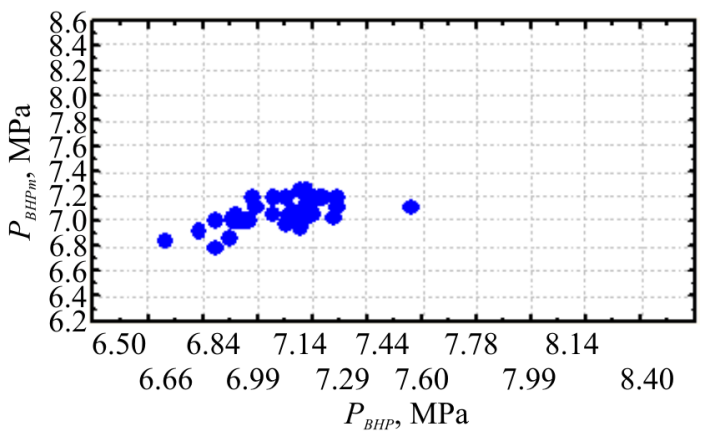

The $6^{\text {th }}$ variant

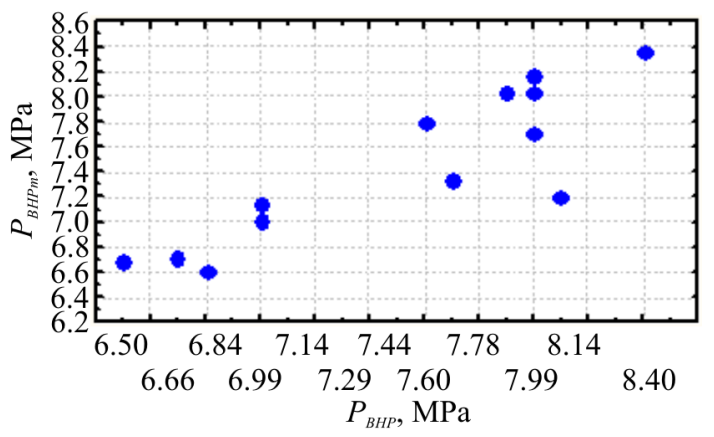

The $8^{\text {th }}$ variant

Fig. 3. Correlation fields between $P_{B H P}$ и $P_{B H P m}$ 
Then the model was constructed to reflect the classes extracted using the method LDF, taking into account the wells division into two classes of parity and odd samples (option 5). Considering these constraints the following model was constructed:

$$
\begin{gathered}
P_{B H P m}^{3}=3.736+0.208301 Q_{l}+ \\
+0.000192 H_{d}-0.108676 Q_{o}
\end{gathered}
$$

if $R=0.799, p<0.00000$.

Then, according to this model $P_{B H P m}^{3}$ values were calculated for examination sample. $P_{B H P}$ comparison with $P_{B H P m}^{3}$ for the examination sample is shown in Fig. 3 (option 6).

According to the models values $P_{B H P m}^{2}$ and $P_{B H P m}^{3}$ have been identified comparison with $P_{B H P}$ was carried out by the correlation field construction between the them (see Fig. 3).

Then testing three constructed models functionality was made for other wells of the same design object (wells 206, 209 and 216) in two versions. In the first case the 1st model was used for calculation without taking into account the division LDF (option 7). In the second case, calculations were made taking into account the division into classes using LDF on models 2 and 3 (option 8). $P_{B H P}$ value in the range of $6.6-8.2 \mathrm{MPa}$ were used to test. This is caused by estimating functionality of the constructed models only in interpolation interval. The analysis of constructed correlation fields was carried out. The constructed according to the training sample (option 1) correlation field consists of two subfields even at a visual level. A similar field is observed according to the examination sample. This indicates that the data are quite similar. Correlation field constructed considering division into classes using LDF (option 3) shows that the visual division into classes is no longer visible. A similar field is observed according to the examination of the sample (option 4). If $P_{B H P m}$ values, data on training and exam, and their comparison with $P_{B H P}$ (option 5 and 6) are used in the training then there is their division into zones (see Fig. 3). For option 5 correlation field is located in the upper right corner of the chart to version 6 is located the bottom left corner. It should be noted that for option 5, $r=0.77$, while for option $6 r=0.65$. These relationships are statistically significant. Let's perform functional test of constructed models for wells 206, 209 and 216 (options 7, 8). In the event that the model 1 is used, the connection between $P_{B H P}$ and $P_{B H P m}$ is not observed $(r=-0.12)$. The connection between $P_{B H P}$ and $P_{B H P m}$ is a direct and statistically significant $(r=0.87)$ in constructing the model using the LDF and calculating $P_{B H P m}$ values on models 2 and 3 . Thus, we can conclude that the use of changing in time $P_{B H P}$ values the can more accurately predict the $P_{B H P m}$ value by circumstantial evidence.

\section{Conclusions}

The following main conclusions can be drawn on the results of the research:

1. 1. The BHP in mechanized wells without depth measurement systems is determined by the dynamic level recalculation according to known methods with significant inaccuracies.

2. Mathematical processing of production data (BHP, oil rates and liquid, water content, etc.) of the Yurchukskogo field well allowed developing a technique of construction of multidimensional models, which can be used in other fields to determine BHP from the known values of other indicators of well operation.

3. The validity of the obtained results with the use of constructed multidimensional models tested by the example of the other three wells of the development of the object.

\section{References}

1. Lekomtsev A.V., Mordvinov V.A., Turbakov M.S. Ekspluatatsiia dobyvaiushchikh skvazhin elektrotsentrobezhnymi nasosami na neftianykh mestorozhdeniiakh Verkhnego Prikam'ia [Submersible pumps operation in wells at oilfields in Verkhnee Prikamje]. Neftianoe khoziaistvo, 2010, no.10, pp.144-145.

2. Lekomtsev A.V., Mordvinov V.A., Turbakov M.S. Otsenka zaboinykh davlenii $\mathrm{v}$ dobyvaiushchikh skvazhinakh Shershnevskogo mestorozhdeniia [Estimation of bottom-hole pressure in producing wells of Shershnevkoe oilfield]. Neftianoe khoziaistvo, 2011, no.10, pp.30-31.
3. Murav'ev I.M., Khalikov G.A., Iurin I.Ia. Privedenie davlenii, zamerennykh na glubinakh vyshe glubiny davleniia nasyshcheniia, $\mathrm{k}$ zaboinym usloviiam [Bringing pressures measured at depths above the saturation pressure's depths to downhole conditions]. Neftianoe khoziaistvo, 1960, no.8, pp.26-29.

4. Carvalho P.M., Podio A.L., Sepehrnoori K. An electrical submersible jet pump for gassy oil wells. Journal of Petroleum Technology, 1999, may, p.34-35. DOI: 10.2118/0599-0034-JPT.

5. Vremennoe metodicheskoe rukovodstvo po raschetu rezhimov skvazhin, ekspluatiruemykh 
glubinnymi nasosami (ETsN i ShGN) [Temporary methodological guidance on the modes calculation in wells exploited with borehole pumps (ESP and SRP)]. Ufa: BashNIPIneft', 1976, 114 p.

6. Gron V.G., Mishchenko I.T. Opredelenie zaboinogo davleniia $\mathrm{v}$ dobyvaiushchikh skvazhinakh, oborudovannykh ustanovkami pogruzhnogo nasosa [Determination of the bottomhole pressure in production wells equipped with submersible pump units]: ucheb. posobie. Moscow: Izd-vo GANG, 1993, $128 \mathrm{p}$.

7. Mishchenko I.T. Raschety pri dobyche nefti i gaza [Calculations during oil and gas production]. Moscow: Neft' i gaz, 2008, 295 p.

8. Lekomtsev A.V., Mordvinov V.A. K otsenke zaboinykh davlenii pri ekspluatatsii skvazhin elektrotsentrobezhnymi nasosami [On estimation of bottomhole pressures in wells operation with electric centrifugal pumps]. Nauchnye issledovaniia $i$ innovatsii, 2011, vol.5, no.4, pp.29-32.

9. Drozdov A.N. Tekhnologiia i tekhnika dobychi nefti pogruzhnymi nasosami v oslozhnennykh usloviiakh [Technology and technics of oil production using submersible pumps under complicated conditions]: ucheb. posobie dlia vuzov. Moscow: RGU nefti i gaza im. I.M. Gubkina, 2008, 616 p.

10. Lea J.F., Minissale J.D. Beam pumps surpass ESP efficiency. Oil and Gas Journal, 1992, May 18, p.72.

11. McCoy J.N., Podio A.L., Huddleston K.L. Acoustic determination of producing bottomhole pressure. SPE Fomation Evaluation, 1985, august, p.617-621. DOI: 10.2118/14254-PA.

12. Podio A.L., McCoy J.N., Becker D. Integrated well performance and analysis. SPE Computer Applications, 1992, June, p.43-48. DOI: 10.2118/24060-PA.

13. Lekomtsev A.V., Mordvinov V.A. Opredelenie davleniia u priema elektrotsentrobezhnykh nasosov po dannym issledovanii skvazhin [Determination of pressure in receiving electrical pumps according to the data of the researched well]. Vestnik Permskogo natsional'nogo issledovatel'skogo politekhnicheskogo universiteta. Geologiia. Neftegazovoe i gornoe delo, 2012, no.4, pp.84-90.
14. Gmurman V.E. Teoriia veroiatnostei i matematicheskaia statistika [Theory of probability and mathematical statistics]: ucheb. posobie dlia vuzov. 4 izd., ispr. i dop. Moscow: Vysshaia shkola, 1972, $368 \mathrm{p}$.

15. Dement'ev L.F. Statisticheskie metody obrabotki i analiza promyslovo-geologicheskikh dannykh [Statistical methods for processing and analysis of the field and geological data]. Moscow: Nedra, 1966, $206 \mathrm{p}$.

16. Barkovskiî S.S., Zakharov V.M., Lukashov A.M., Nurutdinova A.R., Shalagin S.V. Mnogomerny $\breve{1}$ analiz dannykh metodami prikladnoĭ statistiki [Multivariate data analysis by methods of applied statistics]. Kazan', 2010, 126 p.

17. Davaatseren B., Golovko A.K., Tuya M. A study of the ozonolysis and mechanochemical treatment on the properties of the high paraffinic Tamsagbulag Oil (Mongolia). Scientific reports of $M A S$. Ulan-bator, 2006, vol.182, no.4, pp.59-68.

18. Putilov I.S., Galkin V.I. Primenenie veroiatnostnogo statisticheskogo analiza dlia izucheniia fatsial'noi zonal'nosti turne-famenskogo karbonatnogo kompleksa Sibirskogo mestorozhdeniia [The results of statistical analysis for study fades characterization of T-Fm stage of Sibirskoe oilfield]. Neftianoe khoziaistvo, 2007, no.9, pp.112-114.

19. Putilov I.S. Razrabotka tekhnologii kompleksnogo izucheniia geologicheskogo stroeniia i razmeshcheniia mestorozhdenii nefti i gaza [Development of technologies for a comprehensive study of the geological structure and location of oil and gas fields]. Perm': Izd-vo Perm. nats. issled. politekhn. un-ta, 2014, $285 \mathrm{p}$.

20. Galkin V.I., Kozlova I.A. Razrabotka veroiatnostno-statisticheskikh regional'no-zonal'nykh modelei prognoza neftegazonosnosti po dannym geokhimicheskikh issledovanii verkhnedevonskikh karbonatnykh otlozhenii [Development of probabilistic-statistical regional-zoning models of oil and gas potential prediction based on the data of geochemical studies of the Upper Devonian carbonate deposits]. Geologiia, geofizika $i$ razrabotka neftianykh i gazovykh mestorozhdenii, 2016, no.6, pp.40-45.

\section{Список литературы}

1. Лекомцев А.В., Мордвинов В.А., Турбаков М.С. Эксплуатация добывающих скважин электроцентробежными насосами на нефтяных месторождениях Верхнего Прикамья // Нефтяное хозяйство. -2010 . - № 10. - С. 144-145.
2. Лекомцев A.В., Мордвинов В.А., Турбаков М.С. Оценка забойных давлений в добывающих скважинах Шершневского месторождения // Нефтяное хозяйство. 2011. - № 10. - C. 30-31. 
3. Муравьев И.М., Халиков Г.А., Юрин И.Я. Приведение давлений, замеренных на глубинах выше глубины давления насыщения, к забойным условиям // Нефтяное хозяйство. - 1960. № 8. - C. 26-29.

4. Carvalho P.M., Podio A.L., Sepehrnoori K. An electrical submersible jet pump for gassy oil wells // Journal of Petroleum Technology. - 1999. May. - P. 34-35. DOI: 10.2118/0599-0034-JPT.

5. Временное методическое руководство по расчету режимов скважин, эксплуатируемых глубинными насосами (ЭЦН и ШГН). - Уфа: БашНИПИнефть, 1976. - 114 с.

6. Грон В.Г., Мищенко И.Т. Определение забойного давления в добывающих скважинах, оборудованных установками погружного насоса: учеб. пособие. - М.: Изд-во ГАНГ, 1993. - $128 \mathrm{c}$.

7. Мищенко И.Т. Расчеты при добыче нефти и газа. - М.: Нефть и газ, 2008. - 295 с.

8. Лекомцев А.В., Мордвинов В.А. К оценке забойных давлений при эксплуатации скважин электроцентробежными насосами // Научные исследования и инновации. - 2011. - Т. 5, № 4. С. 29-32.

9. Дроздов А.Н. Технология и техника добычи нефти погружными насосами в осложненных условиях: учеб. пособие для вузов. - М.: Изд-во РГУ нефти и газа им. И.М. Губкина, 2008. - 616 с.

10. Lea J.F., Minissale J.D. Beam pumps surpass ESP efficiency // Oil and Gas Journal. 1992. - May 18. - P. 72.

11. McCoy J.N., Podio A.L., Huddleston K.L. Acoustic determination of producing bottomhole pressure // SPE Fomation Evaluation. - 1985. August. - P. 617-621. DOI: 10.2118/14254-PA.

12. Podio A.L., McCoy J.N., Becker D. Integrated well performance and analysis // SPE Computer Applications. - 1992. - June. - P. 4348. DOI: $10.2118 / 24060-P A$.
13. Лекомцев А.В., Мордвинов В.А. Определение давления у приема электроцентробежных насосов по данным исследований скважин // Вестник Пермского национального исследовательского политехнического университета. Геология. Нефтегазовое и горное дело. - 2012. - № 4. - С. 84-90.

14. Гмурман B.Е. Теория вероятностей и математическая статистика: учеб. пособие для вузов. - 4-е изд., испр. и доп. - М.: Высшая школа, 1972. - $368 \mathrm{c}$.

15. Дементьев Л.Ф. Статистические методы обработки и анализа промыслово-геологических данных. - М.: Недра, 1966. - 206 с.

16. Многомерный анализ данных методами прикладной статистики / С.С. Барковский, B.М. Захаров, А.М. Лукашов, А.Р. Нурутдинова, С.В. Шалагин. - Казань, 2010. - 126 с.

17. Davaatseren B., Golovko A.K., Tuya M. A study of the ozonolysis and mechanochemical treatment on the properties of the high paraffinic Tamsagbulag Oil (Mongolia) // Scientific reports of MAS. - Ulan-bator, 2006. - Vol. 182, № 4. - P. 59-68.

18. Путилов И.С., Галкин В.И. Применение вероятностного статистического анализа для изучения фациальной зональности турнефаменского карбонатного комплекса Сибирского месторождения // Нефтяное хозяйство. 2007. - № 9. - С. 112-114.

19. Путилов И.С. Разработка технологий комплексного изучения геологического строения и размещения месторождений нефти и газа. - Пермь: Изд-во Перм. нац. исслед. политехн. ун-та, 2014. - 285 с.

20. Галкин В.И., Козлова И.А. Разработка вероятностно-статистических региональнозональных моделей прогноза нефтегазоносности по данным геохимических исследований верхнедевонских карбонатных отложений // Геология, геофизика и разработка нефтяных и газовых месторождений. - 2016. - № 6. - С. 40-45.

Please cite this article in English as:

Chernykh I.A. Determination of bottomhole pressure by using multivariate statistical models (on example of formation TL-BB Yurchukskoie field). Bulletin of PNRPU. Geology. Oil \& Gas Engineering \& Mining, 2016, vol.15, no.21, pp.320-328. DOI: $10.15593 / 2224-9923 / 2016.21 .3$

Просьба ссылаться на эту статью в русскоязычных источниках следующим образом:

Черных И.А. Определение забойного давления с помощью многомерных статистических моделей (на примере пласта ТЛ-ББ Юрчукского месторождения) // Вестник Пермского национального исследовательского политехнического университета. Геология. Нефтегазовое и горное дело. - 2016. - Т.15, №21. - С.320-328. DOI: 10.15593/2224-9923/2016.21.3 